\title{
A Reflection on the Role of Communal Resource Mobilization on Project Performance for Rural Development, Evidence from Kalungu District
}

Babirye Grace Nabulime ${ }^{{ }^{*}}$, Byabashaija Deusdedit ${ }^{1}$, Issa Ndungo ${ }^{1}$

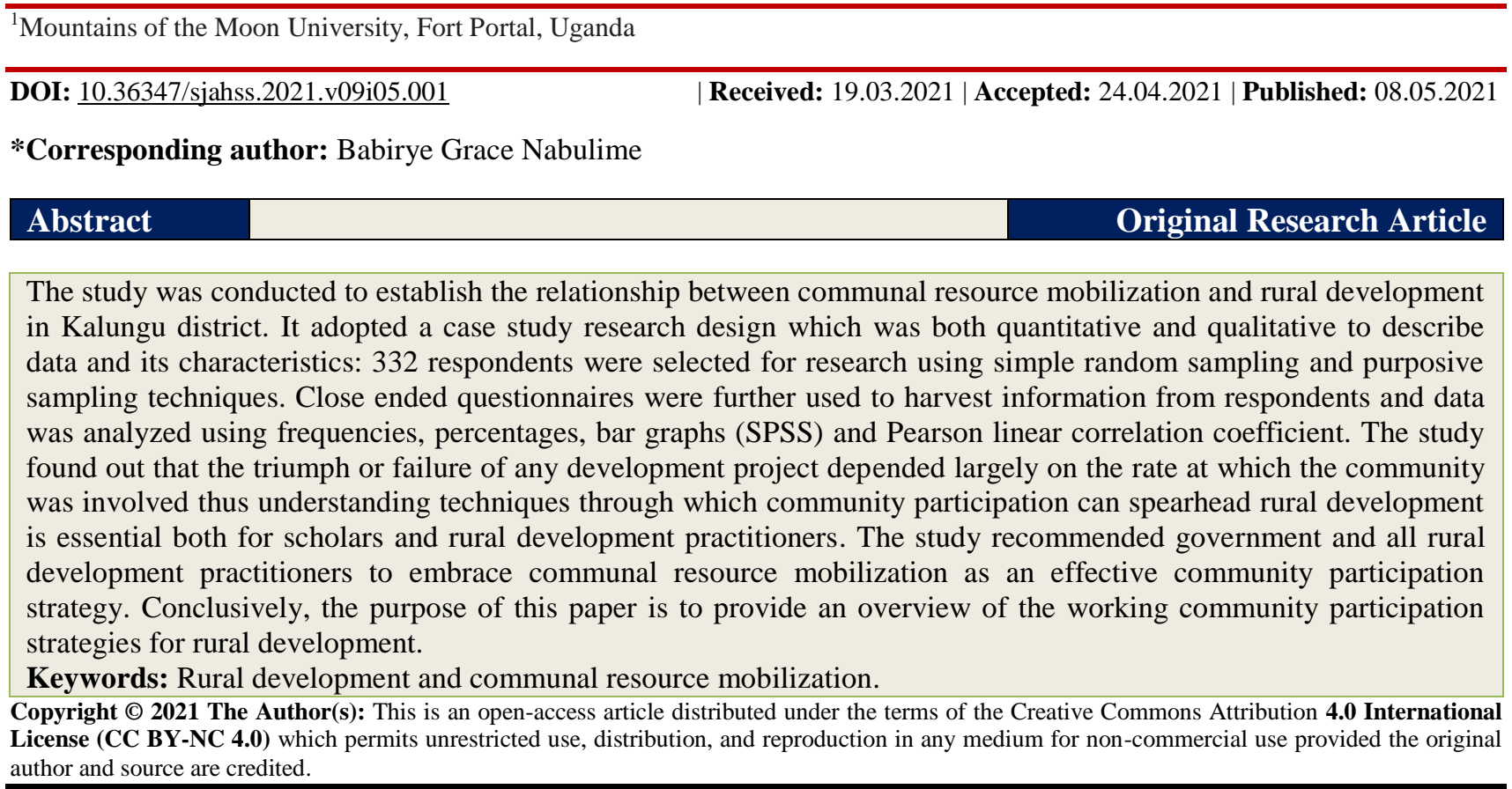

\section{INTRODUCTION}

Resource mobilization refers to the process of assembling resources plus all activities involved in securing new and additional resources [1]. FAO [2] explains that resource mobilization focuses on ongoing partnerships built on trust and mutual accountability so as to attract adequate and more voluntary contributions to community projects. It is for that sake that Namubiru $\mathrm{N}$ [3] called for trusted partnership and honest of development practitioners to realize people's engagement in resource mobilization for project success of Kalungu district.

Financial self-reliance and sustainability for community based organization is essential yet external funding for projects happens to be inconstant therefore, the need for community support based on the real needs of the grass roots [4]. To realize an innovative fundraising strategy, the CBO projects must first focus on current activities, prioritize them and then must diversify accordingly, take up income generating activities, making use of resources available to generate funds and involving volunteers to raise funds.

Rural development literary means improving well-beings of people as well as giving them equal opportunities through coordinating all activities within the rural community that are geared towards promoting people's quality of life [5-7]. Robert chamber [8] defines rural development as a strategy to enable a specific group of people (small scale famers, tenants, landless, poor men and women) to gain what they want and need for themselves and their children. Rural development is also seen from an increase in agriculture production, demographic factors and the rate of urbanization which defines economic growth of a given geographical area.

In this study, rural development is understood by the accomplishment of ongoing projects in rural areas of Kalungu district. This is because all proposed projects target to solve existing community problems and eventually reap development for instance; the smooth function of an agricultural project means economic productivity and food security, water projects indicate access to clean and safe water, Rural electrification victory means accessibility to energy, achievement in a health project definitely brings access to basic health services just like a well-constructed school eases access to education services. 
Rural areas majorly survive on agriculture hence for successful transformation it is essential that agriculture posts high with sustained growth of at least 5.6 percent per annum. Unfortunately, this is not the case as growth in the sector is still low, averaging one percent per annum, between 2008 and 2016 [9]. Because of this sluggish trend in the economic growth, escalating poverty and famine is experienced in some parts of the country and most especially the rural areas of Kalungu district.

In this study, considering population growth which determines the rate of urbanization for each district is fundamental.

Table-1: Average Household Size and Population Growth rates: Kalungu in comparison with other districts

\begin{tabular}{|l|l|l|l|l|l|l|l|}
\hline District & $\mathbf{2 0 0 2}$ & $\mathbf{2 0 1 4}$ & $\begin{array}{l}\text { No of } \\
\text { H/Hs }\end{array}$ & $\begin{array}{l}\text { Growth } \\
\text { rate } \\
\mathbf{2 0 0 2 - 2 0 1 4}\end{array}$ & $\begin{array}{l}\text { Population } \\
\text { Density }\end{array}$ & $\begin{array}{l}\text { Urbanization } \\
\text { level }\end{array}$ & $\begin{array}{l}\text { Average } \\
\text { Household } \\
\text { Size }\end{array}$ \\
\hline Bukomansimbi & 139.6 & 151.4 & 34,335 & 0.7 & 252 & 8.5 & 4.4 \\
\hline Kalungu & 160.7 & 183.2 & 41,437 & 1.1 & 225 & 4.4 & 4.3 \\
\hline Masaka & 228.2 & 297 & 75,765 & 2.2 & 256 & 34.8 & 3.8 \\
\hline Mpigi & 187.8 & 250.5 & 60,511 & 2.4 & 208 & 17.3 & 4 \\
\hline Wakiso & 908 & 1997.4 & 502,089 & 6.6 & 1060 & 59.2 & 3.9 \\
\hline
\end{tabular}

Source: 2014 National Housing and Population Census Report

Considering health as a basic necessity, there is too much pressure on the existing health facilities of Kalungu district mainly on Health Centre II (HC II) and Health Centre III (HCIII), drug shops, clinics and traditional birth attendants. In most parishes, people rely on these facilities, which are poorly facilitated in terms of (staff, drugs, and modern diagnostic facilities). Because of that, patients have to be referred to HC VI e.g. Wakiso or even Mulago National Referral hospital (Kampala). Facilities are overstretched and inadequate as they are characterized by insufficient stock of drugs, limited of or no qualified medical personnel, and lack of modern facilities for proper diagnosis. The major health concerns of all the project area include malaria, water borne Diseases such as diarrhea and dysentery, and respiratory diseases (a consequence of air Pollution particularly from fossil fuel combustion and waste burning) and HIV/AIDS. Other health issues include inadequate human resources for health services, funding for health projects and in adequate health infrastructure [9]. All this happens amidst potentially failing or idle projects which are not communally supported yet they seek to complement service delivery.

Further, considering education as a basic need and energy an indicator of development. Table-2 below illustrates the percentage distribution of Education levels in Kalungu District per Sub County. Yet Table-3 explains energy distribution in some areas of Uganda, Kalungu respectively.

Table-2: Percentage distribution of Education levels in Kalungu District

\begin{tabular}{|c|c|c|c|c|c|c|c|}
\hline Sub County & \multicolumn{7}{|l|}{ Highest level attained } \\
\hline & Population above 5 yrs & None & Primary & Secondary & Tertiary & Didn't Know & Total \\
\hline Bukulula & 37,264 & 14.4 & 64.9 & 16.1 & 1.2 & 3.5 & 100.0 \\
\hline Kalungu & 29,929 & 16.6 & 59.4 & 16.7 & 2.4 & 4.9 & 100.0 \\
\hline Kyamuliibwa & 25,215 & 18.5 & 62.5 & 14.6 & 1.4 & 3.1 & 100.0 \\
\hline Lukaya TC & 21,319 & 12.9 & 52.5 & 27.8 & 4.8 & 2.1 & 100.0 \\
\hline Lwabenge & 24,852 & 21.5 & 64.6 & 10.0 & 2.2 & 1.7 & 100.0 \\
\hline Total & $\mathbf{1 3 7 , 0 9 3}$ & 16.7 & 61.3 & 16.8 & 2.2 & 3.0 & 100.0 \\
\hline
\end{tabular}

Source: UBOS (2010) [9]

Table-3: Distribution of Household by source of Energy for Lighting in Uganda

\begin{tabular}{|l|l|l|l|l|l|l|l|l|}
\hline District & Electricity & Gas & $\begin{array}{l}\text { Paraffin- } \\
\text { Lantern }\end{array}$ & $\begin{array}{l}\text { Paraffin- } \\
\text { Tadooba }\end{array}$ & Candles & Firewood & Other & Total \\
\hline Bukomansimbi & 5,194 & 100 & 4,015 & 22,539 & 537 & 259 & 1,691 & 34,335 \\
\hline Kalungu & 8,166 & 203 & 5,233 & 25,672 & 795 & 274 & 1,094 & 41,437 \\
\hline Masaka & 28,225 & 260 & 9,936 & 31,791 & 2,640 & 304 & 2,609 & 75,765 \\
\hline Mpigi & 13,314 & 388 & 9,140 & 31,103 & 2,398 & 590 & 3,588 & 60,521 \\
\hline Wakiso & 13,314 & 4055 & 63,304 & 70,528 & 33,040 & 1,994 & 20,035 & 502,089 \\
\hline
\end{tabular}

Source: UBOS (2010) [9]

The genesis of communal resource mobilization draws back in the early African Agrarian development, starting from the traditional mobilization of resources to accomplish community activities like digging wells, roads etc. Rural development in this study refers to the delivered project fueled by resources 
stemming from the community herself. Such projects involve water projects, health, education, security, agricultural etc., unfortunately local revenues have been declining over the past several years' yet financial selfreliance and sustainability for community based organization is essential. To realize an innovative fundraising strategy, development projects must focus on current activities, prioritize them, diversify accordingly, take up income generating activities, utilize networks, make use of available resources, write proposals, and engage in training programs, access financial support from foundations / donors etc [10]. She added that a community must understand its strengths, weaknesses, opportunities and threats to its resources or existence.

Kalungu district in particular has for years tried to embrace communal resource mobilization in her development strategies for instance the Ground waterFed project in Lukaya Town council and Bukulula Sub County which required each household to pay 50,000Ugx. Also the Agriculture Cluster development project (ACDP) called for commitment with land, respondents conversely referred to the above as centrally mothered government projects. Therefore, there is more need to encourage communities to lobby for more resources through improving mobilization strategies, engage in trainings and also look at the sustainability of community initiated projects [11].

Kalungu district was witnessed to have experienced continued project poor performance and at times failure due to limited community involvement for instance, Bindhe 12] noted ten (10) project stall which involved the water dam in Lwabenge, maize mills of Bukulula- Bugonzi and class room blocks. Also [13] noted that the central government sometimes never involved the community and local leaders when proposing projects thus mothering idle projects. The above malfunction in projects automatically accelerated rural underdevelopment evident in the 2014 National housing and population census where $62.2 \%$ households used tin lamps and above $30 \%$ lived below the poverty line. Lately, Kalungu population face a challenge of limited access to basic amenities and cannot use the modern means of production, schools and health facilities are in a sorry state plus majority of the population who still struggle under the poverty line [9].

Much as Kalungu district was taking on income generating activities for all categories, projects like rural electrification, maize mill construction and water extension to parishes of Mukoko, Bugonzi and Kyambala still required resource mobilization, this concern was raised by the technical panning committee for Bukulula sub-county [14]. There was also need to provide security, facility and access to these available resources in the district [15].
The study was guided by the Resource mobilization theory by Mc Cathy. Murnary 2019 supposed that both human and non-human resources are brought together in undertaking development activities for the achievement of sustainable development. The theory is used to study social movements as it focuses on the assets and capacities owned to explain development and outcome of social movements. Drawing on a rational choice approach, resources are defined broadly to include tangible resources such as money and facilities, also intangible resources such as solidarity, cultural commitments and group networks. The theory puts resources at the center of the analysis of social movement as it stresses member's ability to acquire resources and mobilize people towards accomplishing the set goals.

The main purpose of this article is thus to provide an overview of the role of communal resource mobilization on project performance for rural development, the study focused on the existing project experiences of Kalungu district in relation with communal resource mobilization and the rate at which they caused rural development.

\section{METHODOLOGY}

A case study design was adopted as a strategy for doing research, it involved empirical investigations of a particular contemporary phenomenon within its real life context using multiple sources of evidence. Roberta [16] refers to a case study as a research methodology, typically seen in social and life sciences which examines complex phenomenon in the natural setting to increase understanding. The design was adopted since the study was to be carried in the subject's real world thus giving the researcher a good view of the study topic; the study collected information that concerned the role of communal resource mobilization on project performance and rural development of Kalungu district.

Mixed research method involved using both quantitative and qualitative data collection methods [17], this approach is increasingly becoming dominant in social research. A quantitative survey was conducted initially to deepen understanding of the topic in response to a gap in the literature. It was also suitable in the formation of statistically sound statistics which were presented in form of percentages and graphs giving no room for emotional judgments.

Yet under the qualitative method, respondents were allowed to describe the problem and reality was captured by the researcher through explanations and observations. The qualitative aspect was accommodated to enable a broader understanding and also guide faster evaluation of multiple data sets. 
The study selected a total of 332 respondents (sample size) out of 183,232. The Simple Random sampling technique was applied to give each individual in the population of interest an equal chance to be selected as a participant for example; all LC leaders, development practitioners (NGOs) and CBO groups in the area were considered as a randomization procedure was applied to select participants. Also the purposive sampling technique was used to choose participants depending on the role they played in the study.

Primary Data was collected using questionnaires yet secondary data was collected through documents review. The review of documents was done by requesting those with the required documents to avail them for review upon full authorization by the accounting officer. Questionnaires were formulated and distributed; some were self-administered while others were filled with the guidance of the researcher and later collected. Data collection instruments were given to supervisors, colleagues and other experts in research to check on content and validity, this helped to determine the degree to which an instrument would gather the intended information. Feedback from supervisors, colleagues, scholars and other researchers was used to make necessary adjustments on the instruments or a pretest of the instruments was performed and the results were used to verify the reliability of the data.

The internal reliability of the Questionnaire was assessed using Cronbach's Alpha coefficient formula, the study also used content validity index (C.V.I) to test the validity of the research instruments.
$\left(\mathrm{K}^{*}=(\mathrm{CVI}-\mathrm{Pc}) /(1-\mathrm{Pc})[23] \mathrm{Pc}=[\mathrm{N} ! / \mathrm{A}(\mathrm{N}-\right.$ $A$ !].5n where $\mathrm{N}=$ number of experts and $\mathrm{A}=$ Number agreeing on reliability [23] = Mathematical symbol for the product of all positive answers

The primarily collected qualitative data was sorted and grouped into themes. Evaluation and analysis of adequacy of the information was done through coding of data, identifying categories and tabulation to facilitate quantitative analysis using Statistical Package for Social Sciences (SPSS).

All qualitative data was presented using descriptive texts yet descriptive statistics tools and Pearson linear correlation coefficient were utilized to analyze such data.

Data analysis tools included

i. Chi-square was used for testing the relationship between categorical variables a denoted

ii. Descriptive statistics (bar graphs, frequencies, pie charts etc.)

\section{RESULTS}

\section{Resources mobilization in Kalungu district}

The study primarily investigated available resources contributing to rural development and responses varied from one village to another since over 12 villages in Bukulala sub-county had land insecurity due to eviction threats similar to experiences of villages from Kyamulibwa sub-county, Lwabenge sub-county and Lukaya Town council who were undergoing land wrangles [18].

Table-4: Percentage per resources as given by respondents

\begin{tabular}{|l|l|l|l|}
\hline \multirow{2}{*}{\multicolumn{2}{|c|}{}} & \multicolumn{2}{|l|}{ Responses } \\
\cline { 3 - 4 } \multicolumn{2}{|c|}{ Resources You have in community } & N & Percent \\
\cline { 2 - 4 } & Land & 128 & $43.0 \%$ \\
\cline { 2 - 4 } & Crops & 91 & $30.8 \%$ \\
\cline { 2 - 4 } & Animals & 58 & $19.6 \%$ \\
\cline { 2 - 4 } & Human capital & 19 & $6.5 \%$ \\
\hline Total & 298 & $100.0 \%$ \\
\hline
\end{tabular}

Source: Primary data

The study found out that land as a resource was unreliable in most parts of Kalungu district to the extent that very fundamental projects like schools, hospitals and maize mills construction were unsuccessful in villages of Kalangala, Bulingo, Kasasa, Kisanje East, Mukoko North, Kamugombwa, Lusanja and Kisanje West due to land eviction threats. The incidental risk hindered voluntary land contribution which definitely failed project accomplishment in the district, most respondents agreed to have land however relating this to observation, part of the remaining percentage was affected by the forth coming eviction thus could not admit to have land as a resource. This predicament did not only hinder communal resource mobilization but also household development in Kalungu district.

\section{Projects that involved the community in resource mobilization \\ The study intended to find which projects greatly engaged rural communities in resource mobilization therefore, different projects were assessed as given below.}


Table 5: Projects which engaged communities in Resource mobilization

\begin{tabular}{|l|l|l|l|l|}
\hline \multicolumn{2}{|l|}{ Project where community mobilized resources } & \multicolumn{2}{l|}{ Responses } & \multirow{2}{*}{ Percent of Cases } \\
\cline { 2 - 4 } & N & Percent & \\
\hline & Health projects & 113 & $38.0 \%$ & $61.3 \%$ \\
\cline { 2 - 4 } & Water and sanitation projects & 137 & $46.0 \%$ & $74.2 \%$ \\
\hline Agriculture projects & 12 & $4.0 \%$ & $6.5 \%$ \\
\hline Education projects & 36 & $12.0 \%$ & $19.4 \%$ \\
\hline
\end{tabular}

Source: Primary data

Considering responses from participants, $74.2 \%$ water and sanitation projects, followed by $61.3 \%$ health projects demanded for a credit to project leaders within communities. This was because whenever communities surrendered resources profound improvement in performance was marked with commitment and ownership. Reminder goes to education and agriculture projects since they also serve a fundamental role in the developing rural areas.

Table-6: The role of communal resource mobilization on project performance for rural development in Kalungu district

\begin{tabular}{|l|l|l|l|}
\hline \multirow{2}{|c|}{ Communal resource mobilization role } & \multicolumn{2}{l|}{ Responses } \\
\cline { 2 - 4 } & N & Percent \\
\hline & Yields project success & 171 & $57.3 \%$ \\
\cline { 2 - 4 } Builds ownership/commitment & 90 & $30 \%$ \\
\hline Proper resource allocation & 37 & $12.4 \%$ \\
\hline \multicolumn{2}{|l}{ Total } & 298 & $100.0 \%$ \\
\hline
\end{tabular}

\section{Source: Primary Data}

The above table explains project success as number one achievement from communal resource mobilization. This directly recognizes rural development since the study explains the concept of rural development as victory in rural projects.
Challenges faced in communal resource mobilization Since communal resource mobilization is a fundamental aspect of project success, the researcher probed to find out why most rural communities opposed or even rejected resource mobilization activities.

Table-7: Communal resource mobilization challenges

\begin{tabular}{|c|c|c|c|}
\hline \multicolumn{2}{|c|}{ Challenges faced by communal resource Mob. } & \multicolumn{2}{|c|}{ Responses } \\
\hline & & $\mathbf{N}$ & Percent \\
\hline \multirow[t]{5}{*}{$\mathbf{M o}^{\mathrm{a}}$} & Poverty & 91 & $30.4 \%$ \\
\hline & Distrust & 64 & $21.4 \%$ \\
\hline & Ignorance & 27 & $8.9 \%$ \\
\hline & Resistance & 47 & $16.1 \%$ \\
\hline & Limited resources & 69 & $23.2 \%$ \\
\hline \multicolumn{2}{|l|}{ Total } & 298 & $100.0 \%$ \\
\hline
\end{tabular}

Source: Primary data

The table above clearly explains why many people never contributed resources towards existing projects, such challenges worked as an insight to the efforts of the government, NGOs and project leaders.

\section{RECOMMENDATIONS}

Project leaders should involve stakeholders in all stages of project development to achieve success in proposed community projects.

There should be continuous training on proposal writing and resource mobilization to have sustainable sources of funds.

Feedback should be provided to community/ project participants. The government should re-think the approaches used in funding rural community projects.

Future researchers should investigate the effect of politically influenced projects on the rural development of Uganda.

Study should be carried out on the other factors like passive participation, policy effect, NGO influence, and information sharing.

\section{CONCLUSION}

In summary, there is a positive significant correlation between communal resource mobilization and project success which results into rural development. When the community is fully engaged in 
setting priorities and resourcing own projects, development becomes inevitable. It is for that reason that communal resource mobilization should be adopted to inspire the development of rural communities.

\section{REFERENCES}

1. Adam JD. Analog signal processing with microwave magnetics. Proceedings of the IEEE. 1988 Feb;76(2):159-70.

2. Rogers GB, Kozlowska J, Keeble J, Metcalfe K, Fao M, Dowd SE, Mason AJ, McGuckin MA, Bruce KD. Functional divergence in gastrointestinal microbiota in physically-separated genetically identical mice. Scientific reports. 2014 Jun 25;4(1):1-5.

3. Namubiru N. UWEP Report- Ministry of Gender, Labour and Social Development (CDO- Bukulula Sub County). 2017.

4. Saumya- Rajesh P, Krithikadatta J, Velmurugan N, Sooriaprakas C. Post- instrumentation pain after the use of either Mtwo or the SAF system: a randomized controlled clinical trial. International endodontic journal. 2017 Aug;50(8):750-60.

5. Todaro MP. Internal migration and urban employment: Comment. The American Economic Review. 1986 Jun 1;76(3):566-9.

6. World Bank. World development report 1992: Development and the environment. The World Bank; 1992 May 31.

7. Surai PF, Kutz E, Wishart GJ, Noble RC, Speake $\mathrm{BK}$. The relationship between the dietary provision of $\alpha$-tocopherol and the concentration of this vitamin in the semen of chicken: effects on lipid composition and susceptibility to peroxidation. Reproduction. 1997 May 1;110(1):47-51.

8. Robert C. Rural Poverty Unpercelved, Problem an Remedies. World Bank, Staf Working Paper. 1980(400).
9. UBOS. Uganda National Bureau of Statistics Report. 2010.

10. Arora S, Ge R, Neyshabur B, Zhang Y. Stronger generalization bounds for deep nets via a compression approach. InInternational Conference on Machine Learning 2018 Jul 3 (pp. 254-263). PMLR.

11. Lilian OO, Uzochukwu OC, Francisca ON. Business process reengineering and organizational performance of selected automobile firms in Southeast of Nigeria. European Journal of Business, Economics and Accountancy. 2015;3(5):12-45.

12. Bindhe E. Ten projects stall in Kalungu district. 2019. /https://ugandaradionetwork.net

13. Jjingo. The state of Projects in Kalungu district; Daily Monitor 2018.

14. Namubiru S. Decent work environment, employee engagement and turnover intentions among the employees of Kampala Capital City Authority (Doctoral dissertation, Makerere University). (2019).

15. Ssimbwa G, Eze ED, Sheu OS, Okpanachi OA, Afodun AM. Postweaning Consumption of Soy isoflavones Induced Alterations on Some Reproductive Parameters of Prepubertal and Postpubertal Male Wistar Rats. Biochem Physiol. 2018;7(247):2.

16. Roberta AP, Nadège R, Fabienne CV, Denis H. The Relationship between Trail Running Withdrawals and Race Topography. Sports. 2017 Dec;5(4):91.

17. Zegwaard KE, Hoskyn K. A review of trends in research methods in cooperative education. In18th New Zealand Association for Cooperative Education Conference 2015 (pp. 59-62). NZACE.

18. Nakkazi E. Apply to trial Ebola vaccines in DR Congo, says ministry. The Lancet. 2019 Jul 6;394(10192):15-6. 